\title{
Who Qualifies as an Audit Committee Financial Expert Under SEC Regulations and NYSE Rules?
}

Lawrence J. Trautman

Follow this and additional works at: https://via.library.depaul.edu/bclj

\section{Recommended Citation}

Lawrence J. Trautman, Who Qualifies as an Audit Committee Financial Expert Under SEC Regulations and NYSE Rules?, 11 DePaul Bus. \& Com. L.J. 205 (2013)

Available at: https://via.library.depaul.edu/bclj/vol11/iss2/3

This Article is brought to you for free and open access by the College of Law at Digital Commons@DePaul. It has been accepted for inclusion in DePaul Business and Commercial Law Journal by an authorized editor of Digital Commons@DePaul. For more information, please contact digitalservices@depaul.edu. 


\title{
Who Qualifies as an Audit Committee Financial Expert Under SEC Regulations and NYSE Rules?
}

\author{
Lawrence J. Trautman*
}

\section{CONTENTS}

I. Introduction................................... 207

II. Role of the Audit Committee ................. 207

A. Financial Complexity Increases................ 208

B. Role of the External Audit ................... 208

C. Audit Committee Mandate ..................... 209

D. Chronology .............................. 210

E. Sarbanes-Oxley........................... 212

F. Charter Requirement ........................ 215

III. The "Independence" Requirements .............. 216

A. NYSE Requirements ....................... 218

B. Qualification Questionnaire Process............. 218

C. NASDAQ Listing Standards: Director

Independence ............................... 219

IV. The Financial Expert ...................... 221

A. SEC Regulations and Definitions............... 221

B. Integrity............................... 223

C. Company- and Industry-Specific Knowledge ....... 224

1. Insurance ............................ 224

2. Energy: Exploration and Production.......... 224

3. Banking.............................. 226

D. Safe Harbor Provisions ..................... 227

V. Are a CPA and Public Company Audit

EXPERIENCE REQUIRED? ....................... 228

* BA, The American University; MBA, The George Washington University; and J.D., Oklahoma City University School of Law. Mr. Trautman is a past president of the New York and Metropolitan Washington/Baltimore Chapters of the National Association of Corporate Directors. He may be contacted at www.ljtrautman.com. The author wishes to extend particular thanks to the following for their assistance in the research and preparation of this Article: first to my mentor and life-long friend, George Michaely, former chief counsel, division of corporation finance, U.S. Securities and Exchange Commission, for his support and guidance over many years; Urton Anderson (University of Texas, Austin), Dorsey Baskin, Alan Bell, Dennis Beresford (University of Georgia), Max Carrier, John Harkey, Richard Hickok, Rich Howell, Renee Hornbaker, Henry T. C. Hu (University of Texas, Austin), Phil McCormick, Maribess Miller, Palmer Moe, David Reed, Wayne H. Shaw (Southern Methodist University), Mickey Sheinfeld, and Jules Zimmerman. 
A. Background ...............................

B. The Accounting and Auditing Supervision Controversy ...............................

VI. What About Investment Bankers, Venture Capitalists, and Professional Financial Analysts? ...................................

VII. What About Smaller Companies? .............. 231

VIII. Financial Expert Succession Planning .......... 232

A. Best Practice ............................. 232

B. Who Will Govern Information Technology? ....... 232

C. Optimizing the Financial Expert Search ........... 233

IX. Conclusion ................................ 234

\section{Abstract}

During recent years, heightened standards for board audit committee membership have been imposed by the SEC, NYSE, and others. Sarbanes-Oxley requires that the audit committee will be comprised solely of independent directors and that the company must disclose whether at least one of the members of the audit committee is a " $\mathrm{fi}$ nancial expert" and if not, why not. An "audit committee financial expert" is defined as a person who has the following attributes: (1) an understanding of generally accepted accounting principles and financial statements; (2) the ability to assess the general application of such principles in connection with the accounting for estimates, accruals, and reserves; (3) experience preparing, auditing, analyzing or evaluating financial statements that present a breadth and level of complexity of accounting issues that are generally comparable to the breadth and complexity of issues that can reasonably be expected to be raised by the registrant's financial statements, or experience actively supervising one or more persons engaged in such activities; (4) an understanding of internal controls and procedures for financial reporting; and (5) an understanding of audit committee functions.

Many seasoned audit committee chairmen hold the view that audit committee financial experts should be experienced in performing $f i$ nancial accounting functions themselves, rather than simply having supervisory experience over the function. Indicative of this view is that if accounting is the language of business, an audit committee $f i$ nancial expert needs to fluently "speak GAAP and GAAS" to understand the nuances of sophisticated and complex accounting, auditing, internal controls, and SEC regulations.

Who then qualifies as a financial expert? This is a fact-dependent, practical question that must be answered by every board, governance and nominating committee, and audit committee member. My goal here is to examine the technical requirements imposed by law and regulation and to present thoughts as to best practice. 


\section{INTRODUCTION}

During recent years, heightened standards for board audit committee membership have been imposed by the Securities and Exchange Commission (SEC), the New York Stock Exchange (NYSE), and others. ${ }^{1}$ In addition to the mandate that the committee members must be independent, a requirement that the chairperson be a financial expert has been imposed.2 Who then qualifies as a financial expert? Does supervisory experience over the accounting function, e.g. CEO experience, really provide a sufficient understanding of accounting theory and practice for qualification as an audit committee financial expert (ACFE)? This is a fact-dependent, practical question that must be answered by every board, governance and nominating committee, and audit committee member. My goal here is to examine the technical requirements imposed by law and regulation and to present thoughts as to best practice.

\section{Role of the Audit Committee}

The audit committee serves as corporate governance gatekeeper to the corporation's financial reporting. In his excellent landmark article on corporate disclosure, Professor Henry T. C. Hu observes that "[a]ccounting conventions and the particular accounting judgments a corporation makes will significantly affect the depictions of reality found in the corporation's financial statements." 3 To the extent that "such conventions and judgments result in depictions that depart from the true economic state of affairs, and the investor is unable to reverse

1. See, e.g., Disclosure Required by Sections 406 and 407 of the Sarbanes-Oxley Act of 2002, 68 Fed. Reg. 5,110 (Jan. 31, 2003) (to be codified at 17 C.F.R. pts. 228-29, 249); Self-Regulatory Organizations; The NASDAQ Stock Market LLC; Notice of Filing and Immediate Effectiveness of Proposed Rule Change to the NASDAQ Listing Rules to Reflect Changes to the Rules of the Commission, 74 Fed. Reg. 28,750 (June 17, 2009); Self-Regulatory Organizations; American Stock Exchange LLC; Notice of Filing and Order Granting Accelerated Approval to Proposed Rule Change and Amendment No. 1 Thereto Modifying the Exchange's Independent Director and Audit Committee Corporate Governance Standards, 71 Fed. Reg. 71,201 (Dec. 8, 2006).

2. See Disclosure Required by Sections 406 and 407 of the Sarbanes-Oxley Act of 2002, 68 Fed. Reg. at 5,110; Self-Regulatory Organizations; The NASDAQ Stock Market LLC; Notice of Filing and Immediate Effectiveness of Proposed Rule Change to the NASDAQ Listing Rules to Reflect Changes to the Rules of the Commission, 74 Fed. Reg. at 28,750; Self-Regulatory Organizations; American Stock Exchange LLC; Notice of Filing and Order Granting Accelerated Approval to Proposed Rule Change and Amendment No. 1 Thereto Modifying the Exchange's Independent Director and Audit Committee Corporate Governance Standards, 71 Fed. Reg. at 71,201 .

3. Henry T. C. Hu, Too Complex to Depict? Innovation, "Pure Information," and the SEC Disclosure Paradigm, 90 TEx. L. REv. 1601, 1625 (2012). 
engineer his way to the objective reality, a serious disclosure problem arises." 4

\section{A. Financial Complexity Increases}

During recent years, as demonstrated by the 2008-2009 global financial crisis, growth in technological capabilities and quantum advances in internet and computer technologies have changed the focus of risk governance. Accordingly, "[m]odern financial innovation has resulted in objective realities that are far more complex than in the past, often beyond the capacity of the English language, accounting terminology, visual display, risk measurement, and other tools on which all depictions must primarily rely." 5 Professor $\mathrm{Hu}$, the SEC's inaugural Director of the Division of Risk, Strategy, and Financial Innovation (2009-2011), uses JPMorgan Chase's April 2012 derivatives problem as an example:

[S]uch characteristics can be so complex that even "objective reality" is subject to multiple meanings. Given such rudimentary tools and such complex realities, the depictions may offer little more than shadowy, gross outlines of the objective reality, however that reality might be conceived.

... [E]ven a well-intentioned [issuer] either may not truly understand or may not function as if he understands the reality he is charged with depicting.

... Such [an issuer's] activities may be too complex relative to existing depiction tools, and the activities and the organization of the [issuer] itself may be so complex that the [issuer] may suffer from both true misunderstandings and functional misunderstandings of the objective reality it is in. ${ }^{6}$

What impact do increased technological complexity and newlyminted financial instruments (intended to mitigate risk by hedging) have on audit committee composition and requisite skills and experience? How do these needs and the demands of effective information technology governance impact requirements for an audit committee's financial expert(s)? I attempt to address these issues and other considerations.

\section{B. Role of the External Audit}

Dennis Beresford says, "I believe [the external audit] is an integral part of the system that shareholders and our overall capital markets
4. $I d$.
5. Id. at 1602 .
6. Id. 
heavily rely on." 7 Moreover, "Much of our democratic system is built on checks and balances or 'trust but verify,' and the role of the external audit brings an independent point of view to financial reporting that helps make our public markets continue to be arguably the most credible in the world." $8 \mathrm{He}$ continues:

I think it is also important to note that independence, objectivity, and skepticism are qualities that audit committee members insist upon in Chief Financial Officers, Controllers, Chief Accounting Officers, Chief Audit Executives, and other senior finance leaders with whom they work directly. Obviously, these terms would not be applied in exactly the same way as for external auditors. A CFO, for example, receives compensation from the company and wouldn't meet an external auditor's definition of independence. However, the audit committee expects that the CFO's communications to them are independent of his/her personal interests in the company or responsibilities to the CEO, for example. Providing incomplete or incorrect information to the audit committee, or worse yet, withholding information, would be grounds for dismissal for a CFO. ${ }^{9}$

\section{Audit Committee Mandate}

While accounting and financial statement presentation may constitute the language of business, it is the board's audit committee that serves as the frontline integrity gatekeeper to the company's financial statements. In its most recent Principles of Corporate Governance, ${ }^{10}$ the Business Roundtable's Fourth Principle states that management is responsible "under the oversight of the audit committee and the board, to produce financial statements that fairly present the financial condition and results of operations of the corporation and to make the timely disclosures investors need to assess the financial and business soundness and risks of the corporation." 11 In its Fifth Principle, it states that the board is responsible, "through its audit committee, to

7. Letter from Dennis R. Beresford, Ernst \& Young Exec. Professor of Accounting, J.M. Tull Sch. of Accounting at the Univ. of Ga., to the Office of the Sec'y of the PCAOB, 4 (Oct. 11, 2011), available at http://pcaobus.org/Rules/Rulemaking/Docket037/029_Dennis_R_Beresford. pdf; see also Ronald C. Anderson et al., Board Characteristics, Accounting Report Integrity, and the Cost of Debt, 37 J. AccT. \& Econ. 315 (2004).

8. See Letter from Dennis R. Beresford, supra note 7, at 4.

9. Id.

10. Principles of Corporate Governance, Bus. Roundtable (2012), http://businessroundtable. org/uploads/studies-reports/downloads/BRT_Principles_of_Corporate_Governance_-2012_ Formatted_Final.pdf; see Peter B. Oh, Gatekeeping, 29 Iowa J. CoRP. L. 735 (2004).

11. Principles of Corporate Governance, supra note 10, at 2-3; see also Andrew J. Felo et al., Audit Committee Characteristics and the Perceived Quality of Financial Reporting: An Empirical Analysis (Apr. 2003) (unpublished manuscript), available at http:www.ssrn.com/abstract= 401240 (finding that the percentage of audit committee members having expertise in accounting or financial management is positively related to financial reporting quality). 
engage an independent accounting firm to audit the financial statements prepared by management and issue an opinion that those statements are fairly stated in accordance with Generally Accepted Accounting Principles [(GAAP)], as well as to oversee the corporation's relationship with the outside auditor."12

\section{Chronology}

It now seems difficult to believe that the presence and stature of the formalized board audit committee have evolved so much over a relatively few years. During the "early 1900 s, no authoritative accounting or auditing standards existed, and auditors wrote narrative audit reports (free-form) for every company." 13 "By the early 1920s, the narrative auditor's report was reduced to one paragraph in length and was referred to as an audit of the accounts and records whereby the independent auditor would certify the balance sheet as being correct."14 Moreover:

The auditor's report of 1934 was "the first report to have required as opposed to suggested report wording." A[n] [SEC] investigation of McKesson \& Robbins resulted in the 1941 issuance of Accounting Series Release No. 21. This release amended Regulation S-X .... The AIA formally adopted the GAAS standards in 1948, which resulted in several revisions to the auditor's report.

In 1979, based on recommendations from the Commission on $\mathrm{Au}-$ ditor's Responsibilities ("Cohen Commission"), the AICPA's Auditing Standards Board ("ASB") analyzed the standard auditor's report and concluded that "a substantial departure from the existing report, as suggested by [the Cohen Commission] was not needed." The Cohen Commission had specifically recommended expanding the auditor's report to include a discussion about four distinct areas: (1) financial statements, (2) other financial information (unaudited), (3) internal control, and (4) other matters (such as the company's policy statement on employee conduct and meetings with the audit committee). The Cohen Commission also recommended the audi-

12. Principles of Corporate Governance, supra note 10 , at 3 ; see also Jonathan H. Grenier et al., Enhancing Perceived and Actual Audit Committee Effectiveness Through Financial Expert Certification, 6 Current Issues In Auditing A15, A15-A16 (2012) (proposing that the SEC initiate a CPE-driven certification program for audit committee members designated as financial experts).

13. PCAOB Release No. 2011-003, Concept Release on Possible Revisions to PCAOB Standards Related to Reports on Audited Financial Statements and Related Amendments to PCAOB Standards app. A-1 (2011) [hereinafter PCAOB Release No. 2011-003] (citing Marshall A. Geiger, Setting the Standard for the New Auditor's Report: An Analysis of Attempts to Influence the Auditing Standards Board, in 1 Studies in Managerial and FinanCial Accounting 38 (1993)), available at http://pcaobus.org/Rules/Rulemaking/Docket034/Concept_Release.pdf.

14. Id. (quoting Vincent M. O'Reilly et Al., Montgomery's Auditing 636 (11th ed. 1990)) (internal quotation marks omitted). 
tor describe those areas using a series of standardized alternative phrases or paragraphs. ${ }^{15}$

As recently as thirty-something years ago, the audit committee was in its infancy. ${ }^{16}$ Professor James D. Cox states, "Through most of the 1960s few companies had outside directors; the prevalence of outside directors spread with the corporate governance movement of the 1970 s so that having a majority of a public corporation's board be independent became something of a norm by the 1990s." 17 During the 1980s, crisis brought regulation and a call for reforms. The Public Company Accounting Oversight Board (PCAOB) reports that "[a]s a result of congressional hearings leading up to, and recommendations from, the National Commission on Fraudulent Financial Reporting ("Treadway Commission"), a new paragraph, now commonly referred to as the 'scope paragraph' was added to the auditor's report in the 1980s."18 The PCAOB continues:

The scope paragraph states the respective responsibilities of management and the independent auditor, describes the work performed by the auditor, and indicates that sufficient evidence is gathered to provide a reasonable basis for the auditor's opinion. There have been no substantial changes to the required wording of the standard auditor's report since the addition of the scope paragraph. ${ }^{19}$

A study of 850 announcements of newly appointed outside directors to audit committees during the period 1993-2002, before implementation of Sarbanes-Oxley (SOX), found "a significant and positive market reaction to the announcement of new directors with accounting financial expertise but no significant reaction to the announcement of either nonaccounting financial experts or nonfinancial experts."20 Moreover:

15. Id. at apps. A-1 to A-3 (footnotes omitted).

16. See generally Lawrence J. Trautman \& James H. Hammond, Role of the Audit Committee: Update and Implementation, NAT'L Ass'N of Corp. Dirs., Monograph No. 13 (1980).

17. James D. Cox, Managing and Monitoring Conflicts of Interest: Empowering the Outside Directors with Independent Counsel, 48 VILL. L. Rev. 1077, 1077 (2003).

18. PCAOB Release No. 2011-003, supra note 13, at app. A-3. "The Treadway Commission was established in response to the congressional and public scrutiny of the accounting profession after significant business failures such as Drysdale Government Securities, Washington Public Power Supply System, Baldwin-United Corp, and E.S.M. Government Securities. From October 1985 to September 1987, the Treadway Commission studied the financial reporting system in the United States. The Treadway Commission's mission was to identify causal factors that can lead to fraudulent financial reporting and steps to reduce its incidence." Id. at app. A-3 n.12 (citations omitted) (internal quotation marks omitted).

19. Id. at app. A-3.

20. Mark L. DeFond et al., Does the Market Value Financial Expertise on Audit Committees of Boards of Directors?, 43 J. Acct. Res. 153, 158 (2005). 
[B]y finding a positive reaction to the appointment of accounting financial experts .... and finding no reaction to the appointment of nonaccounting financial experts . . . our results are consistent with accounting-based financial skills, but not broader financial skills, improving the quality of the financial reporting environment. Furthermore, by finding that the market reaction is confined to firms with strong corporate governance, our results are also consistent with financial expertise complementing strong governance ....21

Just a few years before SOX, SEC Chairman Arthur Levitt "identified problems regarding audit committee effectiveness."22 As a result, the NYSE and National Association of Securities Dealers jointly established the Blue Ribbon Committee (BRC) on Audit Committee Effectiveness in September 1998.23 Murphy Smith found that "implementation of the BRC recommendations have improved audit committee effectiveness." 24 Audit committees were found to be "more likely to more seriously monitor management when they are actively involved with reviews, meetings with internal and external auditors, and when they are independent. Increasing the frequency of audit committee meetings, the subject of [Smith's] study, is one step toward more effective monitoring." 25 Smith observes that:

Perhaps the BRC was too little too late, and SOX would have been necessary even if the BRC recommendations had been implemented years earlier. Even after BRC and SOX, there will likely be additional stories of failed companies and ineffective or uninformed audit committees in the future, but perhaps they will be fewer than without BRC or SOX.

The importance of this first step by the BRC should not be overlooked as it forced board members to scrutinize performance, prepare guidelines for action, and report actions to the stockholders. ${ }^{26}$

\section{E. Sarbanes-Oxley}

It was the corporate financial fraud found in the cases of Enron, Adelphia Communication, WorldCom, ${ }^{27}$ and the like that led to "not only a tightening of NYSE and NASDAQ listing requirements with

21. Id. at 159.

22. L. Murphy Smith, Audit Committee Effectiveness: Did the Blue Ribbon Committee Recommendations Make a Difference?, 3 Int'L J. Acct., Auditing \& Performance Evaluation 240,240 (2006).

23. Id.

24. Id. at 249.

25. Id. at $249-50$.

26. Id. at 250.

27. See Arthur E. Wilmarth, Jr., Conflicts of Interest and Corporate Governance Failures at Universal Banks During the Stock Market Boom of the 1990s: The Cases of Enron and Worldcom 5 (George Wash. Univ. Law Sch. Pub. Law \& Legal Theory, Working Paper No. 234, 2007), available at $\mathrm{http}: / / \mathrm{ssrn} . \mathrm{com} / \mathrm{abstract}=952486$. 
respect to independent directors, but also with the recent enactment of SOX, which is the first step toward the federalization of corporate governance norms for outside directors." 28 SOX legislation also resulted in the strengthening of audit committee membership requirements of independence and heightened qualifications. Professors Geoffrey C. Hazard and Edward B. Rock state that SOX "is important not because it invents the role of independent director, but because it makes a variety of corporate functions mandatory and vastly increases their legal complexity, and consequently enhances the requirements of corporate judgment that can withstand question or challenge." 29 Under SOX, it is the audit committee, according to Hazard and Rock, which is subject to the most significant change. ${ }^{30}$ The changes are as follows:

- The Audit Committee of a corporation subject to the new regime will be comprised solely of independent directors. Moreover, the company must disclose whether at least one of the members of the Audit Committee is a "financial expert" and if not, why not.

- The Audit Committee statutorily will be "directly responsible for the appointment, compersation, and oversight of the work of any registered public accounting firm employed by that issuer (including resolution of disagreements between management and the auditor regarding financial reporting) for the purpose of preparing or issuing an audit report or related work, and each such registered public accounting firm shall report directly to the audit committee."

- The Audit Committee will have to "establish procedures for(A) the receipt, retention, and treatment of complaints received by the issuer regarding accounting, internal accounting controls, or auditing matters; and (B) the confidential, anonymous submission by employees of the issuer of concerns regarding questionable accounting or auditing matters."

- The Audit Committee will have to pre-approve audit and permissible non-audit services.

- The Audit Committee must have a "charter that addresses a list" of specified duties, responsibilities and purposes, one of which must be to "assist board oversight of (1) the integrity of the com-

28. Cox, supra note 17 , at 1078 . "With respect to federalization of corporate governance, consider section 301 of the Act which calls for an independent audit committee, specifies duties for the audit committee, notably the appointment, compensation and termination of the firm's outside accountant and requires that the audit committee have resources to engage such experts as it needs to discharge its duties." Id. at 1078 n.4.

29. Geoffrey C. Hazard, Jr. \& Edward B. Rock, A New Player in the Boardroom: The Emergence of the Independent Directors' Counsel, 59 Bus. LAw. 1389, 1393 (2004).

30. Id.; see also Gopal V. Krishnan \& Gnanakumar Visvanathan, Reporting Internal Control Deficiencies in the Post-Sarbanes-Oxley Era: The Role of Auditors and Corporate Governance, 11 INT'L J. Auditing 73, 75 (2007). 
pany's financial statements [and] (2) the company's compliance with legal and regulatory requirements ...."

- Part of the Audit Committee's responsibility is to monitor and ensure that the audit engagement team not overstay its permissible term. The term limit is five years on, five years off for the audit partner, and no member of the audit team may accept a financial reporting job with the issuer without first observing a one year cooling off period.

- The Audit Committee must also monitor audit partner compensation to ensure that the audit partner does not get paid based on non-audit services provided to the issuer.

- The Audit Committee will have the authority to engage independent counsel and other advisers it deems necessary, at company expense. ${ }^{31}$

Moreover, SOX "may require the audit committee to be in regular, sometimes continuous, communication with the outside auditors, and members may expect the committee to be at times as a practical matter in continuous session."32 As Hazard and Rock observe:

[A]dditional duties devolve on the Audit Committee as derivative from the increased obligations on other actors. Thus, for example, the CEO and CFO must certify that they have disclosed to the Audit Committee (A) all significant deficiencies in the design or operation of internal controls which could adversely affect the issuer's ability to record, process, summarize, and report financial data and ... (B) any fraud, whether or not material, that involves management or other employees who have a significant role in the issuer's internal controls. ${ }^{33}$

Lawrence E. Mitchell observes that SOX "makes three specific changes in the way we think about corporate governance: first, it brings into the realm of internal governance the gatekeepers that once stood outside the box, including auditors, analysts and lawyers."34 Second, Mitchell writes that "it significantly enhances the legal status of, and centrality of corporate governance to, the chief executive officer and the audit committee, two constituents that have received very little recognition in the law and its literature." 35 Third, Mitchell states:

[B]oth in doing this and in other respects (like the prohibition of loans to officers and certain other conflict of interest transactions), it federalizes an important dimension of the internal laws of corpo-

31. Hazard \& Rock, supra note 29, at 1393-94 (footnotes omitted).

32. Id. at 1394 (internal quotation marks omitted).

33. Id. (quoting Sarbanes-Oxley Act of 2002, Pub. L. No. 107-204, § 302(a)(5)(A)-(B), 116 Stat. 745,777 (codified at 15 U.S.C. $\$ 7241$ (2006))) (internal quotation marks omitted).

34. Lawrence E. Mitchell, The Sarbanes-Oxley Act and the Reinvention of Corporate Governance?, 48 VILL. L. REV. 1189, 1189 (2003).

35. Id. 
rate governance, creating a new (albeit arguably narrow) duty of care for the $\mathrm{CEO}$ and audit committee and reintroducing serious prohibitions on conflict of interest transactions that have eroded to nothingness in the hands of the Delaware judiciary and legislature. ${ }^{36}$

\section{F. Charter Requirement}

We have already seen that the audit committee must have a "charter that addresses a list of specified duties, responsibilities and purposes, one of which must be to assist board oversight of (1) the integrity of the company's financial statements ... [and] (2) the company's compliance with legal and regulatory requirements." 37 Section $121 B$ of the American Stock Exchange Company Guide specifies the following requirements for an audit committee charter:

Each [I]issuer must certify that it has adopted a formal written audit committee charter and that the [A] audit [C]committee has reviewed and reassessed the adequacy of the formal written charter on an annual basis. The charter must specify the following:

[(i)](a) the scope of the audit committee's responsibilities, and how it carries out those responsibilities, including structure, processes, and membership requirements;

[(ii)](b) the audit committee's responsibility for ensuring its receipt from the outside auditors of a formal written statement delineating all relationships between the auditor and the [company] issuer, consistent with Independence Standards Board Standard 1, and the audit committee's responsibility for actively engaging in a dialogue with the auditor with respect to any disclosed relationships or services that may impact the objectivity and independence of the auditor and for taking, or recommending that the full board take, appropriate action to oversee the independence of the outside auditor; [and]

[(iii)](c) the audit committee's purpose of overseeing the accounting and financial reporting processes of the issuer and the audits of the financial statements of the issuer; and

$[(i v)](d)$ the specific audit committee responsibilities and authority set forth in [paragraph (4) of this subs]Section $121 B(4) .{ }^{38}$

36. Id. at 1189-90.

37. Hazard \& Rock, supra note 29, at 1393-94 (quoting NYSE Euronext, Inc., NYSE Listed Company Manual $\S 303 \mathrm{~A} .07$ (b)(i)(A) (2004)) (internal quotation marks omitted).

38. Self-Regulatory Organizations; American Stock Exchange LLC; Notice of Filing and Order Granting Accelerated Approval to Proposed Rule Change and Amendment No. 1 Thereto Modifying the Exchange's Independent Director and Audit Committee Corporate Governance Standards, 71 Fed. Reg. 71,201, 71,202 (Dec. 8, 2006). An example audit committee charter is provided by ExxonMobil, as adopted by its board of directors. Audit Committee Charter, ExxONMOBIL (Apr. 27, 2011), http://www.exxonmobil.com/Corporate/investor_governance_comm_ audit.aspx. 


\section{The "INDEPEndence" Requirements}

The audit committee's role in monitoring and avoiding conflicts of interest and independence is provided by Title II of SOX. ${ }^{39}$ Lawrence E. Mitchell observes, "[M]ost interesting for the link between accounting reform and the federalization of corporate governance is the manner in which Title III, the Corporate Responsibility portion of the Act, links accounting reform with the internal affairs of the corporation." 40 He states:

[E]very listed corporation is required either to have an audit committee composed solely of independent directors or to treat the board as a whole as the audit committee. Two things about the corporate governance aspect of this requirement are notable. First, the Act specifies not only the composition of the audit committee but also the procedures by which the audit committee is to operate, requiring each corporation to provide "appropriate funding" for its audit committee and requiring that the audit committee establish procedures for "the receipt, retention, and treatment of complaints received by the issuer regarding accounting, internal accounting controls, or auditing matters; and the confidential, anonymous submission by employees of the issuer of concerns regarding questionable accounting or auditing matters." While the Act does not specify the exact procedures the audit committee is to adopt, the fact that it specifies the nature of the procedures, including the very substantive one of establishing whistle-blowing chains, goes far toward setting a standard of care that seems already to be substantially in excess of that required generally by state corporate law.

Moreover, the Act not only requires that the audit committee consist of independent directors, but it also defines the meaning of independence, a definition heretofore left to state law, and in a more rigorous way than does, for example, Delaware or New York. The Act defines "independent" as a director who may not "accept any consulting, advisory, or other compensatory fee from the issuer; or be an affiliated person of the issuer or any subsidiary thereof." Both Delaware and New York, at least for some purposes (derivative suit dismissal, for example) have less stringent requirements for independence. In this respect, the Act can be said to have established a higher duty of loyalty for public corporations than currently exists under state law. At a minimum, it federalizes the definition of independent director for general purposes. ${ }^{41}$

The SEC's proposed rule would have required disclosure by a company as to whether or not "its [ACFE] is independent of manage-

39. Mitchell, supra note 34, at 1198.

40. Id.; see also April Klein, Causes and Consequences of Variations in Audit Committee Composition (N.Y. Univ. Ctr. for Law \& Bus., Working Paper No. CLB-00-002, 2000), available at http://ssrn.com/abstract=221779.

41. Mitchell, supra note 34, at 1198-99 (footnotes omitted). 
ment." 42 The SEC received many comments from the public opposed to this disclosure requirement "as unnecessary, noting that Section 301 of [SOX] mandates the [SEC] to direct the self-regulatory organizations to prohibit the listing of any company that does not require all of its audit committee members to be independent." 43 The SEC observed, however, that "not all Exchange Act reporting companies are listed on a national securities exchange or association." 44 The SEC explained, "We believe that investors in these companies would be interested in knowing whether the [ACFE] is independent of management. Therefore, the final rules require a company to disclose whether the person or persons identified as the [ACFE] is independent of management." 45

The proposing release also defined "independent" by reference to section $10 \mathrm{~A}(\mathrm{~m})(3)$ of the Securities Exchange Act of 1934 (Exchange Act). ${ }^{46}$ The SEC received several comments concerned "that this reference may cause some confusion because the securities laws include different definitions of the term 'affiliated,' which is part of the definition used in $[\mathrm{s}]$ ection $10 \mathrm{~A}(\mathrm{~m})(3)$. Therefore, to provide clarity, the final rules refer to the definition of 'independent' used in Item 7(d)(3)(iv) of Schedule 14A." 47 Therefore, the SEC believes this revision ensures the consistent use of the term "independent."

The concept of actual and true independence is still argued. For example, Professors Carcello, Neal, Palmrose, and Scholtz remark that these various regulatory attempts to require independence fail to "consider the CEO's myriad personal connections. So, the CEO's influence can still be exerted through directors who appear independent, but are not independent in fact, if such directors can obtain board membership. One way for this to occur is through CEO involvement in the board selection process." 48 Moreover, "Bilimoria and Piderit ... find that directors are more likely to be appointed to

42. Disclosure Required by Sections 406 and 407 of the Sarbanes-Oxley Act of 2002, 68 Fed. Reg. 5,110, 5,112 (Jan. 31, 2003) (to be codified at 17 C.F.R. pts. 228-29, 249).

43. Id.

44. Id. (noting that only 7,250 listed companies of approximately 17,000 listing companies are in SEC Release No. 33-8173).

45. Id.

46. Id.

47. Disclosure Required by Sections 406 and 407 of the Sarbanes-Oxley Act of 2002, 68 Fed. Reg. at 5,112 (footnote omitted).

48. Joseph V. Carcello et al., CEO Involvement in Selecting Board Members, Audit Committee Effectiveness, and Restatements, 28 Contemp. ACCT. Res. 396, 396 (2009). 
the nominating committee if they have social ties to the CEO or if their demographic profiles match those of top managers." 49

\section{A. NYSE Requirements}

The NYSE rules require that the company have a majority of independent directors. The rules provide that no director will qualify as "independent" unless the board affirmatively determines that the director has no material relationship with the company and its subsidiaries, either directly or as a partner, shareholder or officer of an organization that has a relationship with the company. In evaluating each director's independence, the board considers the NYSE rules as well as all facts and circumstances deemed relevant.

The board, in its business judgment, must determine if the audit committee members are independent, as required by applicable listing standards of the NYSE governing the qualifications of the members of audit committees, including the requirements of the Exchange Act. The function of the audit committee is to assist the board in fulfilling its responsibility to oversee (1) management's conduct of the company's financial reporting process (including management's development and maintenance of systems of internal accounting and financial controls), (2) the integrity of the company's financial statements, (3) the company's compliance with legal and regulatory requirements and ethical standards, (4) the qualifications and independence of the company's outside auditors, and (5) the performance of the company's internal audit function and the outside auditors; and to prepare the audit committee report required by the rules of the SEC to be included in the company's annual proxy statement.

\section{B. Qualification Questionnaire Process}

Section 303A.02 (Independence Tests) of the NYSE Listed Company Manual outlines the requirements for a director to be deemed independent by the NYSE, including the mandate that any board affirmatively determine that a director has no material relationship with the company that would impair independence. To assist in ascertaining the independence of board members, each board member typically completes a qualification questionnaire. Board members are asked to verify biographical information, service on other company boards and committees, and attendance history at board and committee meetings. They are also asked to affirm compliance with all of the

49. Id. at 424 (citing D. Bilimoria \& S.K. Piderit, Board Committee Membership: Effects of Sex-Based Bias, 37 Acad. MGmt. J. 1453-78 (1994)). 
independence standards set forth in the NYSE Listed Company Manual and Company Board of Directors' Guidelines. Further, board members are asked to verify their future interest in serving on the board and their availability and capability to serve, as well as confirm they meet additional qualifications required for continued service, as outlined in its Board of Directors' Guidelines..$^{50}$

After receipt of all completed qualification questionnaires, typically the governance and nomination committee members receive a copy of each questionnaire, along with information regarding each board member's ownership in company equity securities. At the conclusion of this process, the board will affirmatively determine that no director, with the exception of a CEO or other employee or family member who is also a director, has a material relationship with the company that would impair her independence and that each director meets all of the independence requirements set forth in the NYSE Listed Company Manual and Board of Directors' Guidelines. Having completed this process, the company is in the position to attest that its board is comprised of a majority of independent directors, as required in section 303A.01 (Independent Directors Section) of the NYSE Listed Company Manual. ${ }^{51}$

\section{NASDAQ Listing Standards: Director Independence}

The NASDAQ Stock Market's listing standards have required that a majority of the members of a board must qualify as independent, as affirmatively determined by the full board. Company corporate governance guidelines may impose additional independence criteria and state that board membership will be predominantly non-employee directors who, at a minimum, meet the criteria for independence required by NASDAQ. Based on a review of a director's professional and personal affiliations, the board will determine if each, except officers such as a president and chief executive officer or other officers, is an independent director, as defined in the applicable rules for NASDAQ listed companies and the additional standards set forth in the NASDAQ Company Corporate Governance Guidelines. ${ }^{52}$ Effective May 2012, NASDAQ "introduced two new guides, designed to pro-

50. See NYSE Euronext, Inc., NYSE Listed Company Manual § 303A.00 (2012).

51. Id. § 303A.01.

52. During May 2012, NASDAQ introduced two new replacement guides: Initial Listing Guide and Continuing Listing Guide. See NASDAQ OMX Grp. Inc., Initial Listing Guide (2013), available at https://istingcenter.nasdaqomx.com/assets/initialguide.pdf; NASDAQ OMX Grp., Inc., Continued Listing Guide (2013), available at https:/listingcenter.nasdaqomx.com/ assets/continuedguide.pdf. See generally NASDAQ OMX Grp., Inc., Summary of NASDAQ Corporate Governance Proposals (2002), available at http://community.corporatecompliance. 
vide companies and their advisors with a practical guide to being listed on NASDAQ, including important information about listing standards, disclosure and notification requirements and fees." 53 Information, in relevant part, regarding the definition of "Independent Director" is reprinted as follows:

\section{Board of Directors and Committees}

(a) Definitions

(1) "Executive Officer" means those officers covered in Rule 16a-

1(f) under the Act.

(2) "Independent Director" means a person other than an Executive Officer or employee of the Company or any other individual having a relationship which, in the opinion of the Company's board of directors, would interfere with the exercise of independent judgment in carrying out the responsibilities of a director. For purposes of this rule, "Family Member" means a person's spouse, parents, children and siblings, whether by blood, marriage or adoption, or anyone residing in such person's home. The following persons shall not be considered independent:

(A) a director who is, or at any time during the past three years was, employed by the Company;

(B) a director who accepted or who has a Family Member who accepted any compensation from the Company in excess of $\$ 120,000$ during any period of twelve consecutive months within the three years preceding the determination of independence, other than the following:

(i) compensation for board or board committee service;

(ii) compensation paid to a Family Member who is an employee (other than an Executive Officer) of the Company; or

(iii) benefits under a tax-qualified retirement plan, or non-discretionary compensation.

Provided, however, that in addition to the requirements contained in this paragraph (B), audit committee members are also subject to additional, more stringent requirements under Rule 5605(c)(2).

(C) a director who is a Family Member of an individual who is, or at any time during the past three years was, employed by the Company as an Executive Officer;

(D) a director who is, or has a Family Member who is, a partner in, or a controlling Shareholder or an Executive Officer of, any organization to which the Company made, or from which the Company received, payments for property or services in the current or any of the past three fiscal years that exceed $5 \%$ of the recipient's consolidated gross revenues for that year, or $\$ 200,000$, whichever is more, other than the following:

org/CORPORATECOMPLIANCE/Communities/Resources/ViewDocument/?DocumentKey= 62dfce86-d3fc-4f5d-b39d-3fa068503b04.

53. NASDAQ OMX Grp., Inc., NASDAQ Regulatory Requirements and Listing Standards and Fees (2012), available at https://listingcenter.nasdaqomx.com/assets/RegRequirements.pdf. 
(i) payments arising solely from investments in the Company's securities; or

(ii) payments under non-discretionary charitable contribution matching programs.

(E) a director of the Company who is, or has a Family Member who is, employed as an Executive Officer of another entity where at any time during the past three years any of the Executive Officers of the Company serve on the compensation committee of such other entity; or

(F) a director who is, or has a Family Member who is, a current partner of the Company's outside auditor, or was a partner or employee of the Company's outside auditor who worked on the Company's audit at any time during any of the past three years.

(G) in the case of an investment company, in lieu of paragraphs (A)-(F), a director who is an "interested person" of the Company as defined in Section 2(a)(19) of the Investment Company Act of 1940 , other than in his or her capacity as a member of the board of directors or any board committee. 54

\section{The Financial Expert}

Whether any particular individual qualifies as a financial expert will require a factual determination by the board based on the person's education, training, and actual relevant experience with respect to the criteria set forth by the SEC. 55

\section{A. SEC Regulations and Definitions}

The board of directors must determine whether any given director meets the qualification guidelines as an ACFE as such term is defined in Item 407(d)(5)(ii) of Regulation S-K promulgated by the SEC. ${ }^{56}$

54. NASDAQ OMX Grp., Inc., NASDAQ Stock Market Rules § 5605 (2013).

55. See generally Joseph V. Carcello \& Terry L. Neal, Audit Committee Composition and Auditor Reporting, 75 AccT. Rev. 453 (2000); Jeffrey R. Cohen et al., Corporate Governance in the Post-Sarbanes-Oxley Era: Auditors' Experiences, 27 ConTEMP. ACCT. Res. 751 (2010); Lawrence A. Cunningham, Rediscovering Board Expertise: Legal Implications of the Empirical Literature, 77 U. CIN. L. Rev. 465 (2008); Mark L. DeFond et al., supra note 20; April Klein, Audit Committee, Board of Director Characteristics, and Earnings Management, 33 J. Acct. \& Econ. 375 (2002); Jagan Krishnan \& Jong Eun Lee, Audit Committee Financial Expertise, Litigation Risk, and Corporate Governance, 28 AUdITING: J. PraC. \& TheORY 241 (2009); Gopal V. Krishnan \& Gnanakumar Visvanathan, Do Auditors Price Audit Committee's Expertise? The Case of Accounting Versus Nonaccounting Financial Experts, 24 J. Acct., AudrTing \& Fin. 115 (2009); Gopal V. Krishnan \& Gnanakumar Visvanathan, Does the SOX Definition of an ACcounting Expert Matter? The Association Between Audit Committee Directors' Accounting Expertise and Accounting Conservatism, 25 Contemp. Acct. Res. 827 (2008); Scott Duellman et al., Audit Committee Financial Experts and Insider Trading (Jan. 4, 2011) (unpublished manuscript), available at http://www.isarhq.org/papers/PS-02_Duellman_Guo_Zhang_Zhou_ISAR_ 2011.pdf.

56. 17 C.F.R. § 229.407(d)(5)(ii) (2012); see Proxy Disclosure Enhancements, 74 Fed. Reg. $68,334,68,364$ (Dec. 23, 2009) (to be codified at 17 C.F.R. pts. 229, 239-40, 249, 274). 
SOX fails to explicitly specify who at the company should determine whether a particular individual meets qualification standards as a financial expert. However, the SEC states, "We believe that the board of directors in its entirety, as the most broad-based body within the company, is best-equipped to make the determination. We think that it is appropriate that any such determination will be subject to relevant state law principles such as the business judgment rule." 57 Accordingly, an ACFE is defined as a person who has the following attributes:

(1) An understanding of [GAAP] and financial statements;

(2) Experience applying [GAAP] in connection with the accounting for estimates, accruals, and reserves that are generally comparable to the estimates, accruals and reserves, if any, used in the registrant's financial statements;

(3) Experience preparing or auditing financial statements that present accounting issues that are generally comparable to those raised by the registrant's financial statements;

(4) Experience with internal controls and procedures for financial reporting; and

(5) An understanding of audit committee functions. ${ }^{58}$

The SEC initially requires that "an individual will have to possess all of the attributes listed in the above definition to qualify as an [ACFE]." 59 Following numerous industry practitioner comments, the SEC decided to eliminate "the proposed requirement that a person's experience applying [GAAP] in connection with accounting for estimates, accruals and reserves be 'generally comparable' to the estimates, accruals and reserves used in the registrant's financial statements."60

Under the final rules, the SEC states:

[A] person must have acquired such attributes through any one or more of the following:

(1) Education and experience as a principal financial officer, principal accounting officer, controller, public accountant or auditor or experience in one or more positions that involve the performance of similar functions;

57. Disclosure Required by Sections 406 and 407 of the Sarbanes-Oxley Act of 2002, 68 Fed. Reg. 5,110, 5,117 (Jan. 31, 2003) (to be codified at 17 C.F.R. pts. 228-29, 249).

58. Id. at 5,112; see also Item 16A(b) of Form 20-F; Paragraph 8(b) of General Instruction B to Form 40-F.

59. Press Release, U.S. Sec. \& Exch. Comm'n, SEC Adopts Rules on Provisions of Sarbanes-Oxley Act (Jan. 15, 2003), available at http://www.sec.gov/news/press/2006/2006134.htm.

60. Id. 
(2) Experience actively supervising a principal financial officer, principal accounting officer, controller, public accountant, auditor or person performing similar functions;

(3) Experience overseeing or assessing the performance of companies or public accountants with respect to the preparation, auditing or evaluation of financial statements; or

(4) Other relevant experience. ${ }^{61}$

\section{B. Integrity}

As is the case for audit committee members and company directors generally, no other factor is as determinative to the likelihood of board governance success as the presence of a director's personal integrity. The SEC addressed this issue:

The fact that a person previously has served on an audit committee does not, by itself, justify the board of directors in "grandfathering" that person as an $[\mathrm{ACFE}]$ under the definition. Similarly, the fact that a person has experience as a public accountant or auditor, or a principal financial officer, controller or principal accounting officer or experience in a similar position does not, by itself, justify the board of directors in deeming the person to be an [ACFE]. In addition to determining that a person possesses an appropriate degree of knowledge and experience, the board must ensure that it names an [ACFE] who embodies the highest standards of personal and professional integrity. In this regard, a board should consider any disciplinary actions to which a potential expert is, or has been, subject in determining whether that person would be a suitable [ACFE]. ${ }^{62}$

Veteran audit committee chairman Philip McCormick states, "I've always believed that personal integrity is the most valuable asset I have-I'm going to do the right thing; my personal integrity is not for sale. Experience has taught me that many human relations issues are wrapped up in integrity and it's a complex subject."63 McCormick continues, "The audit trail for assessing integrity includes looking at a person's work history, examining their prior business associations [and] failed businesses, and any prior questionable financial reporting by any business where he or she has been associated." 64

61. Disclosure Required by Sections 406 and 407 of the Sarbanes-Oxley Act of 2002, 68 Fed. Reg. at 5,113-14; see also Item 401(h)(3) of Regulation S-K; Item 401(e)(3) of Regulation S-B; Item 16A(c) of Form 20-F; Paragraph 8(c) of General Instruction B to Form 40-F.

62. Disclosure Required by Sections 406 and 407 of the Sarbanes-Oxley Act of 2002, 68 Fed. Reg. at 5,116.

63. Telephone Interview with Philip McCormick, professional corporate director and veteran audit committee chairman (Jan. 24, 2012).

64. Id. 


\section{Company- and Industry-Specific Knowledge}

Certain industries present unusually complex accounting and valuation challenges that require an enhanced understanding of and experience with accounting theory and audit practice. ${ }^{65}$ In particular, the insurance, energy, and banking industries come to mind as useful examples of where specialized expertise and experience with complex, technical audit issues may prove helpful.

\section{Insurance}

An audit committee chairman, i.e. a financial expert, of an insurance company will need to be familiar with and have experience understanding the various nuances of insurance accounting concepts such as (1) accounting for cessions, (2) claims incurred, (3) earned premiums, (4) investment accounting, (5) loss ratios, (6) outstanding claims, (7) policy acquisition costs, (8) reinsurance treaties, (9) riskbased capital, (10) solvency margin, and (11) provision for unearned premiums. The methods for calculating these may seem a mystery to the inexperienced. ${ }^{66}$

\section{Energy: Exploration and Production}

An energy exploration and production audit committee chairman will need to be familiar with petroleum reservoir dynamics, the concept of expected production decline curves for a given formation, and all those myriad factors that comprise elements of valuation in the petroleum industry. A vivid example of why this is important may be found in the case of one of the world's largest energy companies by any measure, Royal Dutch Shell. On January 9, 2004, Shell "announced that it would have to reduce its 'proved' oil and gas reserves by 3.9 billion barrels, from 19.5 billion barrels down to 15.6 billion

65. See Baruch Lev, Remarks on the Measurement, Valuation, and Reporting of Intangible Assets, 9 FRBNY Econ. PoL'y Rev. 17, 19 (2003).

66. See Guy Simonet, Insurance Accounting Principles, in Insurance and Private Pensions COMPENDIUM FOR EMERGING ECONOMIEs (Organisation for Economic Co-Operation and Development 2000); see also Karen K. Nelson, The Discretionary Use of Present Value-Based Measurements by Property-Casualty Insurers (Jan. 1999) (unpublished manuscript), available at https:/gsbapps.stanford.edu/researchpapers/library/rp1428r2.pdf. See generally J. DAvid Cummins et al., Cycles and Crises in Property/Casualty Insurance: Causes and ImplicaTIONS FOR PUBlic Policy (Scott E. Harrington \& Robert W. Klein eds., 1991); Martin F. Grace \& J. Tyler Leverty, Political Cost Incentives for Managing the Property-Liability Insurer Loss Reserve, 48 J. Accr. Res. 21 (2010); Douglas O. Cook \& J. David Cummins, Productivity and Efficiency in Insurance: An Overview of the Issues (Oct. 11, 1994) (unpublished manuscript), available at $\mathrm{http}: / / \mathrm{www} . \mathrm{ssrn} . \mathrm{com} / \mathrm{abstract=}=2150$. 
barrels ... represent[ing] $20 \%$ of the Companies' proved reserves." 67 Additionally:

The oil portion of the write-down alone, about two-thirds of the revision, represented $\$ 135$ billion in potential future revenue, assuming moderate oil prices of $\$ 50$ a barrel. The restatement related mainly to reserves booked from 1996 to 2002 .

Shell was forced to cut its reserves three times in the months following the initial January 9, 2004 announcement. On March 18, 2004, Shell announced (1) that the equivalent of 250 million barrels of oil were being reclassified because they did not comply with SEC regulations and (2) that another 220 million barrels of oil equivalent would not be included in the Companies' reported proved reserves for the year ended 2003. On April 9, 2004, Shell cut its reserves by an additional 300 million barrels. On May 24, 2004, the Companies downgraded the size of their proved oil and gas reserves by 103 million barrels. On February 3, 2005, Shell announced yet again that it would have to restate its proved reserves, stating that it was removing from reserves 1.37 million barrels of oil equivalent of oil and gas that were reported as at December 31, 2003. In total, Shell has reduced its previously-reported proved reserves by approximately 6 billion barrels.

In addition to reducing its previously-reported proved reserves, Shell has twice restated its financial results for 2001 and 2002 and once restated its financial results for 2003. The restatements have significantly impacted the Companies' financial results. The first financial restatement, announced on April 19, 2004, caused decreases to net income of $\$ 42$ million for 2001 and $\$ 108$ million for 2002. The second financial restatement, announced on February 3, 2005, caused decreases to net income of $\$ 49$ million for 2001, $\$ 66$ million for 2002 and $\$ 189$ million for $2003 .{ }^{68}$

"It's an imperfect world," notes audit committee chairman Phil McCormick; 69 " $[\mathrm{SOX}]$ says that we must have processes that can be replicated. In a smaller E\&P [exploration and production] company setting, we can derive comfort from an outside petroleum engineering firm's estimate of reserves."70 Moreover, "[ $t]$ he practice of following the assumptions over the years of a highly regarded petroleum engineering firm-allows for a reasonable assessment that the engineering firm is acting responsibly, thereby providing comfort that stated reserves can be relied upon as a fair reflection of what the company

67. See Case History, SHELlSettlement.com, http://www.shellsettlement.com/index.php? page=history (last visited Mar. 6, 2013). See generally David F. Larcker et al., Royal Dutch/Shell: A Shell Game with Oil Reserves (A) (Stanford Graduate Sch. of Bus. 2009).

68. Case History, supra note 67.

69. Telephone Interview with Philip McCormick, supra note 63.

70. Id. 
may actually produce."71 McCormick continues, "Although maybe not required by the rules, in my opinion a 'financial expert' in an E\&P setting should have an understanding of the processes and concepts involved in reserve engineering at the thirty-thousand foot level so that you know what you don't know."72 Then, "a financial expert should have the intelligence to ask probing questions designed to assess the integrity of the process." 73

\section{Banking}

Professor Hu uses the April-May 2012 example of JPMorgan Chase's derivative problem to vividly illustrate how financial misunderstandings require, or may defy, sophisticated knowledge and audit committee leadership and expertise. Accordingly, "[s]tructural factors could cause even the most sophisticated of financial institutions to truly misunderstand or functionally misunderstand the complex financial innovations in which they were involved."74

JPM is among the most sophisticated financial institutions in the world. In September 2008, at the height of the [global financial crisis], Fortune Magazine celebrated JPM's commanding position as last bank standing and emphasized how Dimon and his trusted team of talented lieutenants shared a zeal for sifting piles of data to spot trouble before it happens and vigilantly control risk, even when that means sacrificing growth and losing market share to rivals. Dimon and JPM were so respected that they were at the vanguard of the financial services industry to fend off the impact of Dodd-Frank.

JPM appears to have suffered from both true misunderstandings and functional misunderstandings of the objective reality of the derivatives activities it was engaged in.

In terms of true misunderstandings, as a purely technical matter, JPM was mistaken as to at least three issues: first, the core model that JPM used in measuring risk exposures; second, the general methodology for gauging possible risk exposures; and third, its hedging strategy and the portfolio associated with that strategy. ${ }^{75}$

71. Id.

72. Id.

73. Id.

74. See Hu, supra note 3, at 1671; see also Anette Mikes, Risk Management at Crunch Time: Are Chief Risk Officers Compliance Champions or Business Partners? (May 30, 2008) (unpublished manuscript), available at $\mathrm{http}: / \mathrm{www} . \mathrm{ssrn} . \mathrm{com} / \mathrm{abstract}=1138615$.

75. Hu, supra note 3, at 1671-72 (footnotes omitted) (internal quotation marks omitted); see also Michel Benaroch \& Vasant Dhar, An Intelligent Assistant for Financial Hedging (Ctr. for Digital Econ. Research, Working Paper No. IS-91-33, 1992), available at http://archive.nyu.edu/ bitstream/2451/14391/1/1S-91-33.pdf (observing that problems in finance, particularly those involving risk assessment and management, have been slow to yield to expert technology because the knowledge involved, such as that about financial instruments, is constantly changing, making it difficult to keep a rules base accurate). 


\section{Safe Harbor Provisions}

A threshold question surrounding designation as an ACFE is whether such designation will increase "or decrease his or her duties, obligations or potential liability as an audit committee member."76 While a few commentators to the proposed rule "recommended a formal safe harbor from liability for [ACFEs]," the SEC in its final rule noted, "Unlike the provisions of the Act that impose substantive requirements, ${ }^{77}$ the requirements contemplated by Section 407 are entirely disclosure-based."78 Moreover, "We find no support in [SOX] or in related legislative history that Congress intended to change the duties, obligations or liability of any audit committee member, including the [ACFE], through this provision."79 In addition, the SEC states in its final rule:

In the proposing release, we stated that we did not believe that the mere designation of the [ACFE] would impose a higher degree of individual responsibility or obligation on that person. Nor did we intend for the designation to decrease the duties and obligations of other audit committee members or the board of directors.

We continue to believe that it would adversely affect the operation of the audit committee and its vital role in our financial reporting and public disclosure system, and systems of corporate governance more generally, if courts were to conclude that the designation and public identification of an [ACFE] affected such person's duties, obligations or liability as an audit committee member or board member. We find that it would be adverse to the interests of investors and to the operation of markets and therefore would not be in the public interest, if the designation and identification affected the duties, obligations or liabilities to which any member of the company's audit committee or board is subject. To codify this position, we are including a safe harbor in the new audit committee disclosure item to clarify that:

- A person who is determined to be an [ACFE] will not be deemed an "expert" for any purpose, including without limitation for purposes of Section 11 of the Securities Act, as a result of being designated or identified as an [ACFE] pursuant to the new disclosure item;

76. Disclosure Required by Sections 406 and 407 of the Sarbanes-Oxley Act of 2002, 68 Fed. Reg. 5,110, 5,116 (Jan. 31, 2003) (to be codified at 17 C.F.R. pts. 228-29, 249).

77. Id. "For example, the Sarbanes-Oxley Act requires the Commission to direct the selfregulatory organizations by rule to mandate the independence of all audit committee members of companies listed on national securities exchanges and associations. As another example, Section $\mathbf{4 0 2}$ of the Sarbanes-Oxley Act prohibits certain loans made by companies to their directors and executive officers." Id. at 5,116 n.34 (citation omitted).

78. Id. at 5,116 .

79. Id. 
- The designation or identification of a person as an [ACFE] pursuant to the new disclosure item does not impose on such person any duties, obligations or liability that are greater than the duties, obligations and liability imposed on such person as a member of the audit committee and board of directors in the absence of such designation or identification; and

- The designation or identification of a person as an [ACFE] pursuant to the new disclosure item does not affect the duties, obligations or liability of any other member of the audit committee or board of directors. 80

This safe harbor clarifies that any information in a registration statement reviewed by the [ACFE] is not "expertised" unless such person is acting in the capacity of some other type of traditionally recognized expert. Similarly, because the [ACFE] is not an expert for purposes of Section 11, he or she is not subject to a higher level of due diligence with respect to any portion of the registration statement as a result of his or her designation or identification as an [ACFE].

In adopting this safe harbor, we wish to emphasize that all directors bear significant responsibility. State law generally imposes a fiduciary duty upon directors to protect the interests of a company's shareholders. This duty requires a director to inform himself or herself of relevant facts and to use a "critical eye" in assessing information prior to acting on a matter. Our new rule provides that whether a person is, or is not, an [ACFE] does not alter his or her duties, obligations or liabilities. We believe this should be the case under federal and state law. ${ }^{81}$

\section{Are a CPA and Public Company Audit EXPERIENCE REQUIRED?}

\section{A. Background}

"When the SEC initially proposed those rules [about who qualifies as an ACFE] pursuant to [SOX], they were met with significant opposition," says Dennis Beresford. ${ }^{82}$ As the SEC sought comments to its proposed disclosures required by sections 406 and 407 of SOX, the SEC noted that many comments received criticized specific provisions of the proposed financial expert definition as being too narrow. In particular, many commenters asserted that the SEC's proposed requirement that an expert have direct experience preparing or auditing

80. "Although other audit committee members may look to the [ACFE] as a resource on certain issues that arise, audit committee members should work together to perform the committee's responsibilities. The safe harbor provides that other audit committee members may not abdicate their responsibilities." Disclosure Required by Sections 406 and 407 of the Sarbanes-Oxley Act of 2002, 68 Fed. Reg. at 5,117 n.36.

81. Id. at 5,116-17 (footnotes omitted).

82. Letter from Dennis R. Beresford, supra note 7, at 12. 
financial statements was greatly, and needlessly, restrictive. Other commenters were concerned that the requirement that a person has had experience with financial statements presenting issues generally comparable to those raised by the company's financial statements might have anti-competitive effects if the SEC interpreted this requirement to mean that a financial expert would need previous experience with financial statements of other companies in the same industry. ${ }^{83}$

\section{B. The Accounting and Auditing Supervision Controversy}

Item (iii) of the proposed rule specified that the financial expert must have "experience preparing or auditing financial statements that present accounting issues that are generally comparable to those raised by the registrant's financial statements." ${ }^{4}$ "The result was very watered down final rules that allow individuals who served in senior executive positions to qualify even when they have very little actual accounting or auditing experience," says Beresford. ${ }^{85}$

"I've long been an advocate of strengthening the [ACFE] requirements because I think they don't provide for sufficient understanding of accounting and auditing matters in many cases," observes Beresford, who also serves on the board of directors of the National Association of Corporate Directors and is a member of the PCAOB's Standing Advisory Group. ${ }^{86}$

In particular, I'm concerned that the rules allow former CEOs and others who have supervised finance functions but not performed them themselves to qualify as ACFEs. While some of these individuals are outstanding audit committee members, others simply don't speak GAAP and GAAS sufficiently to understand the nuances of complex and sophisticated accounting, auditing, internal controls, SEC regulations, etc. to be fully effective audit committee members, let alone experts. ${ }^{87}$

Beresford elsewhere observed that this "relatively specific knowledge of GAAP, SEG accounting regulations, and auditing standards ... should be current." 88 Therefore, "a retired financial executive or

83. Disclosure Required by Sections 406 and 407 of the Sarbanes-Oxley Act of 2002, 68 Fed. Reg. at 5,116-17.

84. Id. at 5,114 .

85. Letter from Dennis R. Beresford, supra note 7, at 12.

86. E-mail from Dennis R. Beresford, Ernst \& Young Exec. Professor of Accounting, J.M. Tull Sch. of Accounting at the Univ. of Ga. (Feb. 6, 2012, 8:08 CST) (on file with author) (internal quotation marks omitted).

87. Id.

88. Dennis R. Beresford \& Joseph Hinsey, How 'Expert' Is Your Financial Expert?, HighBEAm Res. (Feb. 1, 2005), http://www.highbeam.com/doc/1P3-803023431.html/print; see 
auditor, undertaking the ACFE responsibilities, must keep up with new pronouncements and other unfolding developments to maintain relevancy." 89 The majority of those commenting who thought that the proposed definition of financial expert was too restrictive focused on this attribute. The SEC was convinced by the weight of the comments that the proposed requirement that an expert have direct experience preparing or auditing financial statements could impose an undue burden on some companies, especially smaller companies that desire to have an ACFE.

\section{What About Investment Bankers, Venture Capitalists, and Professional Financial Analysts?}

May investment bankers, venture capitalists, and professional financial analysts qualify as ACFEs? The SEC was persuaded by commenters' arguments that persons who have experience performing indepth analysis and evaluation of financial statements should not be precluded from being able to qualify as ACFEs if they possess the other four necessary attributes of an expert. ${ }^{90}$ The SEC, therefore, "broadened this attribute by requiring an [ACFE] to have experience preparing, auditing, analyzing or evaluating financial statements." 91

The SEC believes that its "revisions properly capture the clear intent of the statute that an [ACFE] must have experience actually working directly and closely with financial statements in a way that provides familiarity with the contents of financial statements and the processes behind them." 92 The SEC also states:

We also believe that our revisions appropriately broaden the group of persons who are eligible to be [ACFEs]. We recognize that many people actively engaged in industries such as investment banking and venture capital investment have had significant direct and close exposure to, and experience with, financial statements and related processes. Similarly, professional financial analysts closely scrutinize financial statements on a regular basis. Indeed, all of these types of individuals often hold positions that require them to inspect financial statements with a healthy dose of skepticism. They therefore

also Urton Anderson et al., The Role of Reporting Incentives and Quantification in Auditors' Evaluations of Earnings Fluctuations 1 (July 12, 2001) (unpublished manuscript), available at http://www.ssrn.com/abstract=276570 ("To the extent that the auditor fails to appropriately evaluate management-provided information, the effectiveness of the audit and the quality of earnings may be compromised.").

89. Beresford \& Hinsey, supra note 88 , at 3.

90. Disclosure Required by Sections 406 and 407 of the Sarbanes-Oxley Act of 2002, 68 Fed. Reg. 5,110, 5,114 (Jan. 31, 2003) (to be codified at 17 C.F.R. pts. 228-29, 249).

91. Id. (internal quotation marks omitted).

92. Id. 
would be well prepared to diligently and zealously question management and the company's auditor about the company's financial statements. Effective audit committee members must have both the ability and the determination to ask the right questions. Therefore, we have broadened this attribute to include persons with experience performing extensive financial statement analysis or evaluation. ${ }^{93}$

\section{What About Smaller Companies?}

The new disclosure items effective March 31, 2003, "affect issuers that are small entities."94 Accordingly:

Exchange Act Rule 0-10(a) defines an issuer, other than an investment company, to be a "small business" or "small organization" if it had total assets of $\$ 5$ million or less on the last day of its most recent fiscal year. We estimate that there are approximately 2,500 issuers, other than investment companies, that may be considered small entities. The new disclosure items apply to any small entity that is subject to Exchange Act reporting requirements. ${ }^{95}$

Recognizing that smaller companies have fewer resources available to devote to cost effective regulatory compliance, the SEC has convened its Forum on Small Business Capital Formation annually since 1982.96 In his opening remarks to the 2010 Forum, SEC Commissioner Troy A. Paredes observes:

Smaller companies also face distinct challenges and hurdles, some of which are rooted in regulatory requirements that can unduly burden small business. The out-of-pocket financial cost of complying with regulatory obligations can be difficult to bear. In addition, regulatory compliance requires a commitment of time and effort that otherwise could be dedicated to running the business; smaller enterprises may not have excess human resources to distract from day-today operations. Put simply, the disproportionate strain of regulation on small business can create a barrier to entry or expansion. It is important to keep this in mind during our rulemaking because more established firms might not resist regulatory demands that they can bear but that the larger firms' smaller competitors cannot similarly shoulder ....

The practical challenge for securities regulators is to strike a balance that avoids unduly stifling the formation and fostering of new and smaller businesses. Drawing appropriate regulatory distinctions-such as between smaller and larger firms-and scaling regu-

93. Id. at $5,114-15$.

94. Id. at 5,124.

95. Disclosure Required by Sections 406 and 407 of the Sarbanes-Oxley Act of 2002, 68 Fed. Reg. at 5,124 (footnote omitted).

96. See generally 2010 Annual SEC Government-Business Forum on Small Business Capital Formation, U.S. Sec. \& ExChange Commission (Nov. 18, 2010), http://www.sec.gov/info/ smallbus/gbfor29.pdf. 
latory demands accordingly helps strike this balance by guarding against overburdening enterprises that do not present the kinds of concerns that, on balance, may warrant more costly regulation and for which the costs of regulation may prove to be disproportionate. ${ }^{97}$

\section{Financial Expert Succession Planning}

\section{A. Best Practice}

It may take a highly skilled and experienced financial expert several accounting cycles-several years-to become familiar with companyspecific issues relevant to audit committee oversight. The Business Roundtable, in its most recently published Principles of Corporate Governance, highlights the need for thoughtful attention to planning for needed backgrounds and experience in board composition. Accordingly, in its discussion of "How the Board Performs Its Oversight Function," the Business Roundtable observed:

As part of the ongoing assessment of board composition, the board should plan ahead for the nomination of new directors by engaging in succession planning. The board should conduct a forward-looking assessment to identify qualifications and attributes that the board may find valuable in the future based on the corporation's strategic plans, anticipated director retirements and evolving best practices in the corporation's industry. The board also should plan ahead for director departures, considering whether it is appropriate to establish or maintain procedures for the retirement or replacement of board members, such as a mandatory retirement age or term limits. ${ }^{98}$

\section{B. Who Will Govern Information Technology?}

Few operational areas that may fall under the responsibility of the audit committee present as much inherent risk or prove as difficult to govern as IT. Trautman and Altenbaumer-Price have observed:

- IT failures include loss of sensitive and private customer information; loss of sensitive product or financial data of the corporation; virus attacks by hackers on the company's computer systems and those of its customers or vendors; business interruption losses due to IT downtime; as well as theft and use of client credit card data.

- The average loss from a corporate security breach is $\$ 234,000$.

- When public companies announce a breach, it typically causes a five percent drop in share price.

97. Id. at 11-12.

98. Principles of Corporate Governance, supra note 10, at 14. 
- A number of cybersecurity bills have been introduced in Congress.

- At least half of data breaches or losses are believed to be caused by a lack of internal controls and process-not hackers or viruses.

... Boards and executive management need to extend governance, already exercised over the enterprise, to IT by way of an effective IT governance framework. This framework should address strategic alignment, performance measurement, risk management, value delivery, and resource management. IT governance is an integral part of enterprise governance and consists of the leadership and organizational structures and processes that ensure that the organization's IT sustains and extends the organization's strategies and objectives. Simply put, IT governance and the effective application of an IT governance framework are the responsibilities of the board of directors and executive management. ${ }^{99}$

Trautman and Altenbaumer-Price contend that responsible best practice "will dictate that an audit committee include IT expertise and be composed of a qualified vice chairman, familiar with the company's particular audit issues by virtue of experience gained from audit committee service. This will help provide an instant replacement for the committee chair should unexpected developments require."100 In addition, Trautman and Altenbaumer-Price recommend that every board should attempt to have at least two qualified financial experts on their audit committee and "seek IT expertise and experience in director recruitment to help avoid and address the costly private and regulatory lawsuits related to cyber issues." 101

\section{Optimizing the Financial Expert Search}

Board composition and the dynamics of small group decision making play a major role in the effectiveness of any committee. Professor Seletha R. Butler observes that "[a] key challenge for board composition is building a group that can work cohesively, offer constructive dissent, leverage each member's experience to better understand tough issues, ask thought-provoking questions, demand pertinent information, and make the best informed decisions, while consistently adding value."102 Great functioning boards reflect more than just

99. Lawrence J. Trautman \& Kara Altenbaumer-Price, The Board's Responsibility for Information Technology Governance, 28 J. Marshall J. Computer \& INFo. L. 313, 339-40 (2011) (footnotes omitted).

100. Id. at 340 .

101. Id. at 341; see also Lawrence J. Trautman, The Matrix: The Board's Responsibility for Director Selection and Recruitment, 11 FLA. ST. U. Bus. REv. 75 (2012).

102. Seletha R. Butler, All on Board! Strategies for Constructing Diverse Boards of Directors, 7 VA. L. \& Bus. Rev. 61, 70 (2012). 
technical skills; diversity of thought and personal experiences are required, along with the ability to respect and work well with others. "One-third of our board searches are for [ACFEs]," says Theodore L. Dysart, Vice Chairman of Heidrick \& Struggles, a Chicago-based executive search firm. 103 "Those who technically qualify are relatively easy to find-every public company $\mathrm{CEO}$; retired major accounting firm senior executives; and most chief financial officers and controllers meet the technical requirements." $104 \mathrm{He}$ continues:

The challenge is to find those qualified candidates who will make a great board member; those with industry experience at the proper level and also bring the right perspective, stature and presenceand will be able to meaningfully contribute to the future strategy of the enterprise. Following [SOX], best practice seems to call for the new financial expert director to serve on the audit committee for a year or two in order to provide for orderly succession planning ....105

\section{Conclusion}

During recent years, heightened standards for board audit committee membership have been imposed by the SEC, NYSE, and others. SOX requires that the audit committee be comprised solely of independent directors and that the company disclose whether at least one of the members of the audit committee is a financial expert and if not, why not. An ACFE is defined as a person who has the following attributes: (1) an understanding of GAAP and financial statements; (2) the ability to assess the general application of GAAP in connection with the accounting for estimates, accruals, and reserves; (3) the experience preparing, auditing, analyzing or evaluating financial statements that present a breadth and level of complexity of accounting issues that are generally comparable to the breadth and complexity of issues that can reasonably be expected to be raised by the registrant's financial statements, or experience actively supervising one or more persons engaged in such activities; (4) an understanding of internal controls and procedures for financial reporting; and (5) an understanding of audit committee functions.

Many seasoned audit committee chairmen hold the view that ACFEs should be experienced in performing financial accounting functions themselves rather than simply have supervisory experience over the function. Indicative of this view is that if accounting is the lan-

103. Trautman, supra note 101, at 101 (quoting Telephone Interview with Theodore L. Dysart, Vice Chairman, Heidrick \& Struggles (July 14, 2011)) (internal quotation marks omitted).

104. Id.

105. Id. 
guage of business, an ACFE needs to fluently "speak GAAP and GAAS"106 to understand the nuances of sophisticated and complex accounting, auditing, internal controls, and SEC regulations. Determining who qualifies as a financial expert is a fact-dependent, practical question that must be answered by every board, governance and nominating committee, and audit committee member. 
